\title{
A ceRNA approach may unveil unexpected contributors to deletion syndromes, the model of $5 q-$ syndrome
}

\author{
Walter Arancio ${ }^{1}$, Swonild Ilenia Genovese ${ }^{2}$, Lucia Bongiovanni² and Claudio Tripodo ${ }^{2}$ \\ ${ }^{1}$ Biomedical Department of Internal and Specialized Medicine, Palermo University School of Medicine, Palermo, Italy \\ ${ }^{2}$ Tumour Immunology Unit, Human Pathology Section, Department of Health Science, Palermo University School of Medicine, \\ Palermo, Italy \\ Correspondence to: Claudio Tripodo, email: claudio.tripodo@unipa.it
}

Keywords: CeRNA, competing endogenous RNAs, genomic deletions, 5q-syndrome, myelodysplastic syndrome

Received: September 10,2015 Accepted: November 09, $2015 \quad$ Published: November 11, 2015

This is an open-access article distributed under the terms of the Creative Commons Attribution License, which permits unrestricted use, distribution, and reproduction in any medium, provided the original author and source are credited.

\section{ABSTRACT}

In genomic deletions, gene haploinsufficiency might directly configure a specific disease phenotype. Nevertheless, in some cases no functional association can be identified between haploinsufficient genes and the deletion-associated phenotype. Transcripts can act as microRNA sponges. The reduction of transcripts from the hemizygous region may increase the availability of specific microRNAs, which in turn may exert in-trans regulation of target genes outside the deleted region, eventually contributing to the phenotype. Here we prospect a competing endogenous RNA (ceRNA) approach for the identification of candidate genes target of epigenetic regulation in deletion syndromes.

As a model, we analyzed the $5 q-$ myelodysplastic syndrome. Genes in haploinsufficiency within the common 5q deleted region in CD34+ blasts were identified in silico. Using the miRWalk 2.0 platform, we predicted microRNAs whose availability, and thus activity, could be enhanced by the deletion, and performed a genomewide analysis of the genes outside the 5q deleted region that could be targeted by the predicted miRNAs. The analysis pointed to two genes with altered expression in 5q- transcriptome, which have never been related with $\mathbf{5 q}$ - before.

The prospected approach allows investigating the global transcriptional effect of genomic deletions, possibly prompting discovery of unsuspected contributors in the deletion-associated phenotype. Moreover, it may help in functionally characterizing previously reported unexpected interactions.

\section{INTRODUCTION}

The vast majority of human malignancies exhibits chromosomal rearrangements. These rearrangements span from deletions, duplication, balanced and unbalanced translocations, to the gain or loss of whole chromosomes, which are often associated [1-8].

Frequently, specific genomic rearrangements are associated with specific malignant phenotypes.

One notable example is the Philadelphia chromosome being the hallmark of chronic myelogenous leukemia (CML). Philadelphia chromosome is the result of a balanced translocation involving chromosomes 9 and 22 [9]. The final product of this rearrangement is the production of a chimerical protein ( $\left.\mathrm{p} 210^{\mathrm{BCR}-\mathrm{ABL}}\right)$ with constitutive tyrosine kinase activity, which is responsible for the CML clone expansion [10].

The study of the effects of translocations usually leads to the identification of genes at the breakpoints that gain or lose functions and that are causative of the phenotypes observed.

Differently, the study of genomic deletions or duplications is less straightforward because of the rarity of homozygous deletions and since the involved regions are commonly gene-rich.

The main efforts to elucidate the effects of deletions have been focused on the study of every single gene coded within the deleted region. The rationale is that if a gene shows haploinsufficiency, a reduced amount and activities of the gene products can contribute to the phenotype [11- 
35].

For example, in Williams syndrome the $7 \mathrm{q} 11.23$ band is deleted. The deleted region includes more than 25 genes, comprising the $E L N$ gene. $E L N$ gene codes for the elastin protein, and its haploinsufficiency is associated with the typical cardiovascular abnormalities of the syndrome [36].

Interestingly, very often this axiomatic relationship between genic deletion and phenotype is not easily identified. This is the case of 5q- syndrome [9], which we have adopted as a model to test a novel in silico approach to investigate the global effect of deletions. The 5qsyndrome is a hematological disorder characterized by the loss of the $5 \mathrm{q} 31.1$ band in bone marrow hematopoietic cells. This chromosome abnormality usually leads to a myelodysplastic syndrome (MDS) that can also evolve towards acute myeloid leukemia (AML) [37-42]. In the commonly deleted region of 5q-, several genes have been suggested to play a role in the syndrome, such as $S P A R C, R P S 14$ and $h s a-m i R-145$, all of them contributing to specific features of the $5 \mathrm{q}$ - myelodysplasia. However, the reduced activity of such genes does not explain every facet of the complex phenotype of 5q- syndrome [37-42].

In order to investigate the global effect of the $5 \mathrm{q}$ deletion, we prospected a competing endogenous RNAs (ceRNA) approach. CeRNA rationale relies on the consideration that RNA transcripts regulate one another by competing for shared microRNAs [43-48]. The loss or haploinsufficiency of a specific gene can free a certain amount of regulating microRNAs that, in turn, can act in-trans to regulate a subset of other transcripts. CeRNA approach has given interesting results both in oncological and non-oncological diseases. Usually, competing RNAs are explored using a single bait gene, as in the case of PTEN [49, 50], LMNA [51, 52], SOX2 [53], hTERT [54]. To the best of our knowledge, the effect of the loss of a pool of genes, as in the case of a deletion, using a ceRNA approach, has never been investigated before.

In 5q- syndrome, we selected, by in silico analyses, a set of microRNAs that might be freed by the haploinsufficiency of the genes coded within the deleted region, and identified the genes that could be regulated by the microRNA set as a whole.

This approach, which extends the research for ceRNAs from a single bait gene, to a set of genes, allows identifying those genes whose activity can be perturbed by a genomic deletion, considered as a whole. Notably, it could provide an explanation to the phenotypes observed in syndromes caused by deletions, independently from the genes coded within the deleted region.

\section{RESULTS AND DISCUSSION}

Over the last few years, it has become clear that different RNA species can cross-talk and regulate one another [43-48, 55-59]. Due to a hemizygosis condition, several species of RNAs can be downregulated compared to a wild type condition. This global loss of transcripts might have an impact on the RNA-mediated cellular systems of regulation. In particular, we investigated if this loss of transcripts could have an impact on microRNAmediated systems of regulation. MicroRNAs are small non-coding RNAs that regulate the gene expression, mostly at a post-transcriptional level [60-64]. In particular, RNA transcripts can regulate one another by competing for shared microRNAs. The RNAs that regulate one another in this way are called competing endogenous RNAs or ceRNAs. Competitive endogenous RNAs cross-regulation involves sequestration of shared microRNAs and gives rise to rather complex regulatory networks [43-48].

The loss of several transcripts at once during a deletion might free a sufficient amount of microRNAs that can assert a detectable effect in trans outside from the deleted region. Moreover, if several genes in haploinsufficiency within the deleted region are regulated by the same set of microRNAs, we might be able to identify a deletion-specific signature characterized by an increased activity of specific microRNAs.

In brief, a deletion could have an impact on the activity of a specific set of microRNAs that may in turn alter the activity of genes outside the deleted region and apparently unrelated with the genomic deletion. This alteration might contribute to determine the phenotypes of deletion syndromes.

In order to test our hypothesis, we used the 5qsyndrome model to investigate if a ceRNA approach could be useful to identify unexpected contributors to deletion syndromes. The approach adopted is graphically summarized in Figure 1.

We took advantage of the published GDS3795 affymetrix array dataset [65], which collects the global gene expression profiling of bone marrow CD34+ cells of myelodysplastic syndrome patients and healthy controls.

We first identified the patients with $5 \mathrm{q}$ deletion as the only reported genomic abnormality (see Supplemental data), and then, using their expression data, we selected the genes in haploinsufficiency within the common $5 \mathrm{q}$ deleted region, which are listed in Table 1.

Using the bioinformatics approach described in the Methods section, we identified a set of microRNAs that putatively regulate the genes in haploinsufficiency. Each gene was regulated by a different set of microRNAs, but overall some microRNAs regulate a larger set of genes. Organizing those microRNAs in a hierarchical order, we were able to identify the most represented microRNAs. MicroRNAs that putatively regulated at least 5 of the haploinsufficient genes within the $5 \mathrm{q}$ - deleted region were selected. These included: hsa-miR-3164, hsa-miR-513a5p, hsa-miR-30c-1-3p, hsa-miR-1254, hsa-miR-3916, hsa-miR-27a-3p, hsa-miR-27b-3p, hsa-miR-4311, and hsa-miR-665 (see Supplemental data).

We then looked for genes that were predicted to be 
Table 1: Identification of haploinsufficient genes within the commonly deleted region of $5 q$ -

\begin{tabular}{|c|c|c|c|c|c|c|c|c|}
\hline Gene name & Mean 5q- & SD 5q- & SE 5q- & Mean CNTR & SD CNTR & SE CNTR & $\mathrm{p}$-value & $\mathrm{p}<0.05$ \\
\hline ABLIM3 & 48.59779 & 58.31375 & 10.82859 & 22.49942 & 4.97781 & 1.2073 & 0.07359 & \\
\hline AFAP1L1 & 12.05416 & 3.3277 & 0.61794 & 15.09705 & 3.75227 & 0.91006 & 0.00653 & DOWN \\
\hline ANXA6 & 122.24087 & 67.11685 & 12.46329 & 147.35532 & 52.42362 & 12.7146 & 0.19289 & \\
\hline ARHGEF17 & 147.6068 & 37.55099 & 6.97304 & 133.18229 & 28.94435 & 7.02004 & 0.18011 & \\
\hline ARSI & 19.25328 & 3.34174 & 0.62055 & 20.23331 & 7.4089 & 1.79692 & 0.54062 & \\
\hline ATOX1 & 193.08972 & 81.26299 & 15.09016 & 211.23735 & 30.26857 & 7.34121 & 0.38248 & \\
\hline CAMK2A & 32.69334 & 10.36123 & 1.92403 & 32.51296 & 10.37561 & 2.51645 & 0.95483 & \\
\hline CCDC69 & 63.50043 & 31.51593 & 5.85236 & 107.38927 & 32.08788 & 7.78245 & 0.00004 & DOWN \\
\hline CD74 & 38.76174 & 8.96062 & 1.66395 & 40.6401 & 7.54131 & 1.82904 & 0.47179 & \\
\hline CSF1R & 79.69017 & 44.38093 & 8.24133 & 106.02755 & 38.34201 & 9.2993 & 0.04748 & DOWN \\
\hline CSNK1A1 & 59.94675 & 54.80374 & 10.1768 & 101.51224 & 49.24745 & 11.94426 & 0.01347 & DOWN \\
\hline DCTN4 & 47.74753 & 16.37672 & 3.04108 & 68.13771 & 18.98236 & 4.6039 & 0.00039 & DOWN \\
\hline FAT2 & 19.86582 & 3.65128 & 0.67803 & 20.04196 & 3.26452 & 0.79176 & 0.87047 & \\
\hline G3BP1 & 57.54757 & 22.68119 & 4.21179 & 83.12785 & 23.39945 & 5.6752 & 0.00069 & DOWN \\
\hline GLRA1 & 12.83507 & 1.82292 & 0.33851 & 12.48884 & 1.03018 & 0.24986 & 0.4773 & \\
\hline GM2A & 36.88007 & 10.41824 & 1.96886 & 46.9379 & 9.92848 & 2.40801 & 0.00262 & DOWN \\
\hline GPX3 & 36.37417 & 33.64503 & 6.24773 & 37.93556 & 27.76831 & 6.73481 & 0.87237 & \\
\hline GRPEL2 & 64.30569 & 23.59284 & 4.38108 & 98.69718 & 30.05175 & 7.28862 & 0.00009 & DOWN \\
\hline HMGXB3 & 92.76827 & 22.19641 & 4.12177 & 129.66734 & 24.83669 & 6.02378 & 0.000005 & DOWN \\
\hline IL17B & 23.57699 & 3.80584 & 0.70673 & 25.38715 & 2.49688 & 0.60558 & 0.08732 & \\
\hline IRGM & 8.72469 & 1.41946 & 0.26359 & 9.03116 & 0.93882 & 0.2277 & 0.43232 & \\
\hline LOC100652758 & \multicolumn{8}{|c|}{ Data not available } \\
\hline MIR143HG & 45.98064 & 7.97738 & 1.48136 & 44.04348 & 5.67301 & 1.37591 & 0.38484 & \\
\hline MYOZ3 & 126.92361 & 34.89592 & 6.48001 & 138.42359 & 30.43793 & 7.38228 & 0.26498 & \\
\hline NDST1 & 60.03087 & 27.17387 & 5.04606 & 58.14676 & 23.76045 & 5.76275 & 0.81347 & \\
\hline PCYOX1L & 117.69138 & 49.35714 & 9.16539 & 166.65525 & 69.23529 & 16.79202 & 0.0077 & DOWN \\
\hline PDE6A & 23.06221 & 12.30975 & 2.28586 & 20.27092 & 2.3138 & 0.56118 & 0.36191 & \\
\hline PDGFRB & 23.11002 & 7.09533 & 1.31757 & 23.33169 & 3.82961 & 0.92882 & 0.90605 & \\
\hline PPARGC1B & 44.98414 & 17.74701 & 3.29554 & 85.30953 & 26.02103 & 6.31103 & \begin{tabular}{|l|}
0.0000001 \\
\end{tabular} & DOWN \\
\hline RBM22 & 63.53639 & 26.10673 & 4.8479 & 94.33986 & 17.52159 & 4.24961 & 0.00009 & DOWN \\
\hline RPS14 & 7856.9131 & 1234.65184 & 229.26909 & 10598.78235 & 941.02851 & 228.23294 & 0.0000000006 & DOWN \\
\hline SH3TC2 & 14.87956 & 4.13834 & 0.76847 & 14.6208 & 3.05314 & 0.7405 & 0.82371 & \\
\hline SLC26A2 & 114135 & 53.33529 & 9.90411 & 200.29804 & 70.23587 & 17.0347 & 0.00003 & DOWN \\
\hline \begin{tabular}{|l} 
SLC36A1 \\
\end{tabular} & 44.44143 & 14114 & 2.6209 & 46.69696 & 15.60091 & 3.78378 & 0.61728 & \\
\hline SLC36A3 & \multicolumn{8}{|c|}{ Data not available } \\
\hline SLC6A7 & 46.04152 & 6.0099 & 1.11601 & 47.21034 & 6.08871 & 1.47673 & 0.52959 & \\
\hline SMIM3 & 260.38469 & 141.71754 & 26.31629 & 500.79865 & 310.45128 & 75.2955 & 0.00081 & DOWN \\
\hline SPARC & 49.30088 & 41.99314 & 7.79793 & 62.24083 & 28.91624 & 7.01322 & 0.26807 & \\
\hline SYNPO & 110.19731 & 20.31167 & 3.77178 & 115.67666 & 15.80301 & 3.83279 & 0.34516 & \\
\hline TCOF1 & 57.14866 & 25.18242 & 4.67626 & 73.23271 & 19.88939 & 4.82388 & 0.02946 & DOWN \\
\hline TIGD6 & 7.45674 & 0.79702 & 148 & 7.39382 & 0.78457 & 0.19029 & 0.79614 & \\
\hline TNIP1 & 139.14645 & 86.98013 & 16.1518 & 154.56547 & 45.26099 & 10.9774 & 0.50195 & \\
\hline ZNF300 & 96.84063 & 73.90228 & 13.72331 & 86.83198 & 35.88454 & 8.70328 & 0.60446 & \\
\hline
\end{tabular}

A comparison of the normalized expression levels, as reported in GDS3795 dataset, of the genes within the common deleted region between $5 \mathrm{q}$ - patients and controls. The genes that showed in a student's t-test a statistically significant

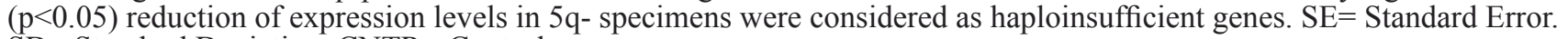
$\mathrm{SD}=$ Standard Deviation. $\mathrm{CNTR}=$ Controls. 
Table 2: Expression levels of the putative ceRNA genes in 5q- samples compared with the controls.

\begin{tabular}{|l|l|l|l|l|l|l|l|l|}
\hline Gene name & Mean 5q- & SD 5q- & SE 5q- & $\begin{array}{l}\text { Mean } \\
\text { CNTR }\end{array}$ & $\begin{array}{l}\text { SD } \\
\text { CNTR }\end{array}$ & $\begin{array}{l}\text { SE } \\
\text { CNTR }\end{array}$ & $p$-value & $p<0.05$ \\
\hline DCX & 11.62274 & 1.82978 & 0.33978 & 10.91179 & 1.54032 & 0.37358 & $\mathbf{0 . 1 8 5 4 3}$ & \\
\hline GRAMD1B & 173.15608 & 48.10625 & 8.93311 & 217.83253 & 40.57191 & 9.84013 & $\mathbf{0 . 0 0 2 4 5}$ & DOWN \\
\hline HIPK2 & 270.99334 & 102.12731 & 18.96457 & 213.90735 & 66.42774 & 16.11109 & $\mathbf{0 . 0 4 5 4 9}$ & UP \\
\hline SLC1A2 & 15.62593 & 2.33554 & 0.4337 & 16.00038 & 2.37252 & 0.57542 & $\mathbf{0 . 6 0 4 3 9}$ & \\
\hline
\end{tabular}

A comparison of the normalized expression levels, as reported in GDS3795 dataset, of the putative ceRNA genes between 5q- patients and controls. The genes that showed in a student's t-test a statistically significant $(\mathrm{p}<0.05)$ difference of expression levels are considered as positive results. $\mathrm{SE}=\mathrm{Standard}$ Error. $\mathrm{SD}=$ Standard Deviation. $\mathrm{CNTR}=$ Controls.

regulated by all of the 9 microRNAs, the rationale being that if these microRNAs could not bind a fraction of their natural targets due to the haploinsufficiency of the $5 \mathrm{q}$-coded genes, they were free to exert their control on the remaining targets, deregulating the control network.

The analysis pointed out 4 genes, namely $D C X$, GRAMD1B, HIPK2 and SLC1A2, which were putatively regulated by all the 9 microRNAs. Among these genes, GRAMD1B and HIPK2, showed significantly different mRNA expression in 5q-CD34+ cells as compared with control CD34+ cells in the same GDS3795 dataset, being significantly down- and up-regulated, respectively. Of note, the two genes that did not show significant variation between $5 \mathrm{q}$ - and control CD34+ cells both showed very low expression levels (Table 2).
GRAMD1B codes for a protein involved in chemoresistance [66] and the rs735665 SNP upstream of its coding sequence has been associated with chronic lymphocytic leukemia (CLL) in a genome-wide association study $[67,68]$.

HIPK2 is part of the AML1 complex, and it activates its transcriptional activity. Noteworthy, AML1 is a frequent target of leukemia-associated mutations. It has been reported that HIPK2 mutations in AML and MDS impair AML1-mediated transcription. It has been therefore suggested that a deregulation of HIPK2 may play a role in the pathogenesis of leukemia [69].

The results obtained through the approach prospected herein have, however, some limitations. Indeed, the algorithms used to identify the interactions

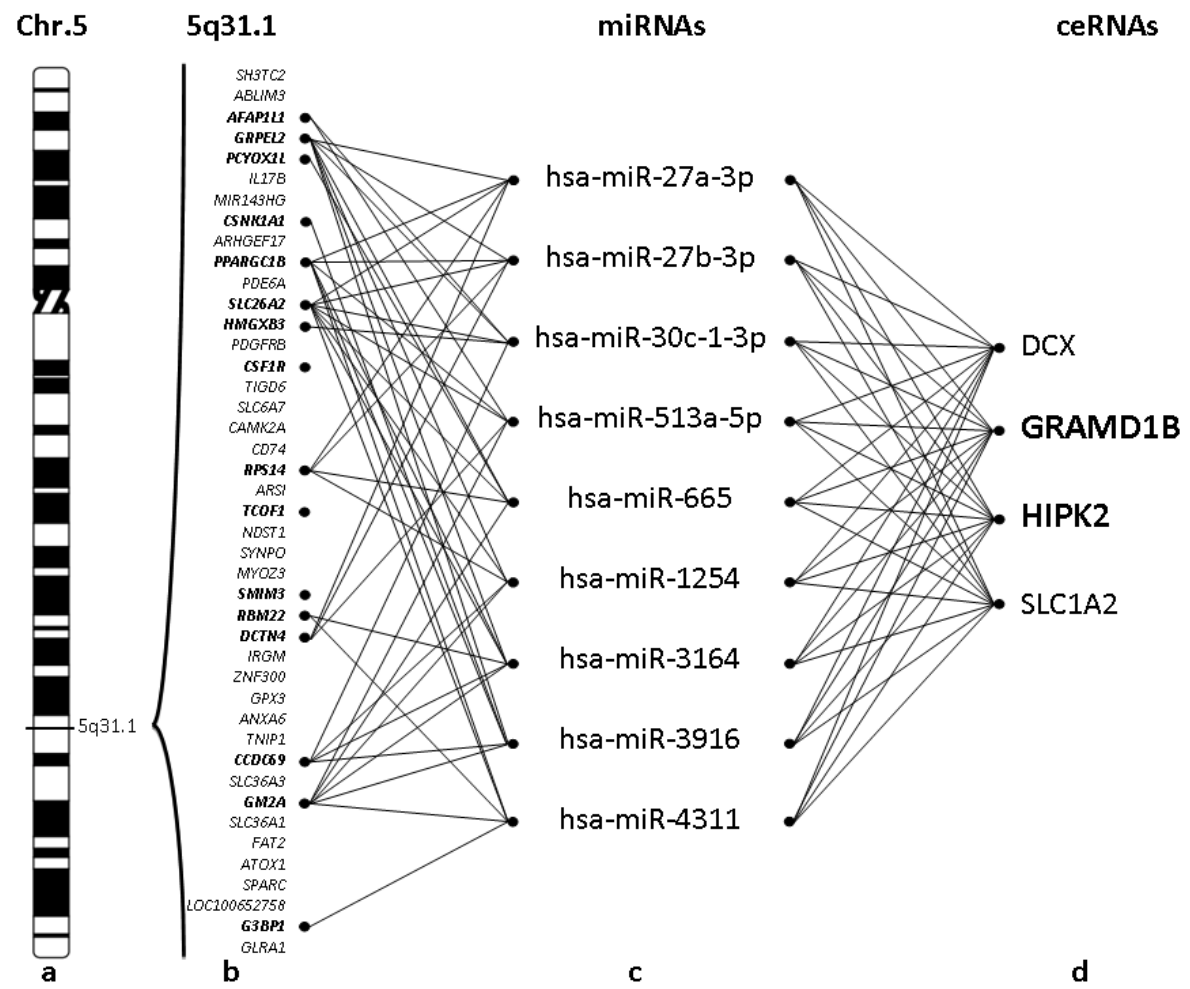

Figure 1: Schematic representation of the ceRNA analysis on 5q deletion. a. The ideogram of human 5 chromosome (modified from David Adler); b. The genes within the common deleted 5q- region (the genes in haploinsufficiency are in bold); c. The microRNAs that regulated 5 or more genes in haploinsufficiency in b; $\mathbf{d}$. The genes that are regulated by the 9 microRNAs in c and that are considered the putative ceRNAs (in bold the genes that show a significant different expression in $5 \mathrm{q}$ - patients compared with the controls). 
between transcripts and microRNAs are still imperfect. Even if the criterion used was highly stringent (i.e. the contemporary detection by 4 of the most used algorithms) the certainty of the result is far from being achieved. The adoption of different algorithms and/or different parameters could lead to different results.

Similarly, the adoption of a different, and less stringent threshold in the selection of microRNAs could have led to different results.

Finally, the interpretation of the results is rather complex. If microRNAs can act only as inhibitors of transcription and translation, the ceRNAs isolated through this analysis should have been consistently downregulated. Instead, the analysis identified $H I P K 2$ that is significantly upregulated in the 5q- patients as compared with controls. It is known that microRNAs can also upregulate the transcription [70-72], and maybe that is the case. Alternatively, HIPK2 upregulation could be the result of complex perturbations of the RNA regulatory network.

Nevertheless, the analysis that we prospected was able to pinpoint two genes significantly modulated in patients, as compared with controls, and whose relationship with $5 \mathrm{q}$ - deletion was never reported before.

The method prospected here represents a novel approach to study the global effects of genomic deletions with the final aim of identifying unexpected contributors to the genomic deletion phenotypes and could deserve experimental validation. The same approach might be used to study duplications or complex rearrangements, leading to a new strategy to question complex syndromes and phenotypes that at the moment are not fully understood.

\section{MATERIALS AND METHODS}

The published GDS3795 affymetrix array dataset [65] was used to select the genes in haploinsufficiency within the common $5 \mathrm{q}$ deleted region [73] in bone marrow $\mathrm{CD} 34+$ cells of myelodysplastic syndrome patients. We selected patients that showed only $5 \mathrm{q}$ - deletion without other reported rearrangements. In detail, we selected 29 patients (MDS patient $4,5,6,7,8,10,11,12,14,15$, $21,23,24,26,31,35,36,45,58,62,70,90,95,109$, $121,132,135,154,168)$ and compared them with the 17 healthy controls of the dataset (Supplemental data).

The expression levels of the genes within the common deleted region between 5q- patients and controls were compared. The genes that showed in a student's t-test a statistically significant $(\mathrm{p}<0.05)$ reduction of expression levels in $5 \mathrm{q}$ - specimens were considered as haploinsufficient genes (Table 1). As expected, no genes showed an increase in expression levels.

The miRWalk 2.0 [74] platform was used to identify the microRNAs that putatively regulate the genes in haploinsufficency. We considered as positives the microRNAs that recognize the 3'UTR of the genes, with a minimum seed length of 7 and from miRNA seed position 1, with a maximum of p-value of 0.05 in all of the 4 algorithms embedded in the platform used during the analysis: miRWalk [74], miRanda [75], RNA22 [76] and TargetScan [77]. If a gene was recognized multiple times by the same microRNA, it was considered as a single hit in the following analyses. This collection of microRNAs was then organized in a hierarchical order from the most present to the less, and only microRNAs that putatively regulated 5 or more genes in haploinsufficiency were selected for the following analyses. The threshold of 5 was selected to harvest a sufficient number of microRNA to continue the analysis, ideally in the range of the number of microRNAs that can control a single gene, from 4 to 20 [78] (Supplemental data).

Using the miRWalk 2.0 platform with the same parameters described above, the genes putatively regulated by this pool of microRNAs were identified, and those genes that resulted regulated by all the microRNAs were selected. The expression levels of the candidate genes were then analyzed in the same samples from the GDS3795 dataset.

\section{ACKNOWLEDGMENTS}

The Authors are grateful to Dr. Mario Paolo Colombo and to Professor Pier Paolo Piccaluga for inspiring discussion.

\section{CONFLICTS OF INTEREST}

No potential conflicts of interest are present.

\section{GRANT SUPPORT}

This work was supported by AIRC (Italian Cancer Research Association) and by University of Palermo.

\section{REFERENCES}

1. Miller CR, Stephens D, Ruppert AS, Racke F, McFaddin A, Breidenbach H, Lin HJ, Waller K, Bannerman T, Jones JA, Woyach JA, Andritsos LA, Maddocks K, Zhao W, Lozanski G, Flynn JM, Grever M, Byrd JC, Heerema NA. Jumping translocations, a novel finding in chronic lymphocytic leukaemia. Br J Haematol. 2015; 170(2):200-7.

2. Villa N, Redaelli S, Lissoni S, Saccheri F, Sala E, Crosti F, Dalprà L, Carrino V, Pioltelli P, Isimbaldi G. Lymph node hyperplasia: clonal chromosomal and genomic rearrangements. Report of two new cases and literature review. Cancer Genet. 2014; 207:12-8.

3. Bridge JA. The role of cytogenetics and molecular diagnostics in the diagnosis of soft-tissue tumors. Mod Pathol. 2014; 27 Suppl 1:S80-97.

4. Mullighan CG. Molecular genetics of B-precursor acute lymphoblastic leukemia. J Clin Invest. 2012; 122:3407-15. 
5. Gianfelici V, Lahortiga I, Cools J. Chromosomal aberrations and fusion genes in myeloid malignancies. Expert Rev Hematol. 2012; 5:381-93.

6. Dong H, Wang S. Exploring the cancer genome in the era of next-generation sequencing. Front Med. 2012; 6:48-55.

7. Kasparek TR, Humphrey TC. DNA double-strand break repair pathways, chromosomal rearrangements and cancer. Semin Cell Dev Biol. 2011; 22:886-97.

8. Thompson SL, Compton DA. Chromosomes and cancer cells. Chromosome Res. 2011; 19:433-44.

9. Swerdlow SH, Campo E, Harris NL, Jaffe ES, Pileri SA, Stein H, Thiele J, Vardiman JW. WHO Classification of Tumours of Haematopoietic and Lymphoid Tissues. Lyon, France: IARC Press; 2008. ISBN-13: 9789283224310.

10. Jabbour E, Kantarjian H. Chronic myeloid leukemia: 2014 update on diagnosis, monitoring, and management. Am J Hematol. 2014; 89:547-56.

11. Giorgio E, Robyr D, Spielmann M, Ferrero E, Di Gregorio E, Imperiale D, Vaula G, Stamoulis G, Santoni F, Atzori C, Gasparini L, Ferrera D, Canale C, et al. A large genomic deletion leads to enhancer adoption by the lamin B1 gene: a second path to autosomal dominant adult-onset demyelinating leukodystrophy (ADLD). Hum Mol Genet. 2015; 24:3143-54.

12. Timoteo AR, Albuquerque BM, Moura PC, Ramos CC, Agnez-Lima LF, Walsh T, King MC, Lajus TB. Identification of a new BRCA2 large genomic deletion associated with high risk male breast cancer. Hered Cancer Clin Pract. 2015; 13:2.

13. Sugimoto S, Yamada H, Takahashi M, Morohoshi Y, Yamaguchi N, Tsunoda Y, Hayashi H, Sugimura H, Komatsu H. Early-onset diffuse gastric cancer associated with a de novo large genomic deletion of CDH1 gene. Gastric Cancer. 2014; 17:745-9.

14. Coutinho MF, da Silva Santos L, Lacerda L, Quental S, Wibrand F, Lund AM, Johansen KB, Prata MJ, Alves S. Alu-Alu Recombination Underlying the First Large Genomic Deletion in GlcNAc-Phosphotransferase Alpha/ Beta (GNPTAB) Gene in a MLII Alpha/Beta Patient. JIMD Rep. 2012; 4:117-24.

15. Kluth M, Hesse J, Heinl A, Krohn A, Steurer S, Sirma H, Simon R, Mayer PS, Schumacher U, Grupp K, Izbicki JR, Pantel K, Dikomey E, et al Genomic deletion of MAP3K7 at $6 \mathrm{q} 12-22$ is associated with early PSA recurrence in prostate cancer and absence of TMPRSS2:ERG fusions. Mod Pathol. 2013; 26:975-83.

16. Arai T, Oh-ishi T, Yamamoto H, Nunoi H, Kamizono J, Uehara M, Kubota T, Sakurai T, Kizaki T, Ohno H. Copy number variations due to large genomic deletion in X-linked chronic granulomatous disease. PLoS One. 2012; 7:e27782.

17. Thomas AD, Orren A, Connaughton J, Feighery C, Morgan BP, Roberts AG. Characterization of a large genomic deletion in four Irish families with $\mathrm{C} 7$ deficiency. Mol Immunol. 2012; 50:57-9.
18. Köhn L, Bowne SJ, S Sullivan L, Daiger SP, Burstedt MS, Kadzhaev K, Sandgren O, Golovleva I. Breakpoint characterization of a novel approximately $59 \mathrm{~kb}$ genomic deletion on $19 \mathrm{q} 13.42$ in autosomal-dominant retinitis pigmentosa with incomplete penetrance. Eur J Hum Genet. 2009; 17:651-5.

19. Ma D, Marion R, Punjabi NP, Pereira E, Samanich J, Agarwal C, Li J, Huang CK, Ramesh KH, Cannizzaro LA, Naeem R. A de novo $10.79 \mathrm{Mb}$ interstitial deletion at 2 q13q14.2 involving PAX8 causing hypothyroidism and mullerian agenesis: a novel case report and literature review. Mol Cytogenet. 2014; 7:85.

20. Neemat K, Rania K, Tarek M, Hamdy AA. Effect of $13 q$ deletion on IL-6 production in patients with multiple myeloma: a hypothesis may hold true. Clin Lab. 2014; 60:1393-9.

21. Honda H, Nagamachi A, Inaba T. -7/7q- syndrome in myeloid-lineage hematopoietic malignancies: attempts to understand this complex disease entity. Oncogene. 2015; 34:2413-2425.

22. Volkert S, Kohlmann A, Schnittger S, Kern W, Haferlach $\mathrm{T}$, Haferlach C. Association of the type of $5 \mathrm{q}$ loss with complex karyotype, clonal evolution, TP53 mutation status, and prognosis in acute myeloid leukemia and myelodysplastic syndrome. Genes Chromosomes Cancer. 2014; 53:402-10.

23. Kasaian K, Wiseman SM, Thiessen N, Mungall KL, Corbett RD, Qian JQ, Nip KM, He A, Tse K, Chuah E, Varhol RJ, Pandoh P, McDonald H, et al. Complete genomic landscape of a recurring sporadic parathyroid carcinoma. J Pathol. 2013; 230:249-60.

24. Kroeger N, Klatte T, Chamie K, Rao PN, Birkhäuser FD, Sonn GA, Riss J, Kabbinavar FF, Belldegrun AS, Pantuck AJ. Deletions of chromosomes $3 p$ and $14 q$ molecularly subclassify clear cell renal cell carcinoma. Cancer. 2013; 119:1547-54.

25. Alahmadi H, Croul SE. Pathology and genetics of meningiomas. Semin Diagn Pathol. 2011; 28:314-24.

26. Vergult S, Dauber A, Delle Chiaie B, Van Oudenhove E, Simon M, Rihani A, Loeys B, Hirschhorn J, Pfotenhauer J, Phillips JA 3rd, Mohammed S, Ogilvie C, Crolla J, et al. 17q24.2 microdeletions: a new syndromal entity with intellectual disability, truncal obesity, mood swings and hallucinations. Eur J Hum Genet. 2012; 20:534-9.

27. Cordoba I, González-Porras JR, Nomdedeu B, Luño E, de Paz R, Such E, Tormo M, Vallespi T, Collado R, Xicoy B, Andreu R, Muñoz JA, Solé F, et al. Spanish Myelodysplastic Syndrome Registry. Better prognosis for patients with $\operatorname{del}(7 q)$ than for patients with monosomy 7 in myelodysplastic syndrome. Cancer. 2012; 118:127-33.

28. Hervé AL, Florence M, Philippe M, Michel A, Thierry F, Kenneth A, Jean-Luc H, Nikhil M, Stéphane M. Molecular heterogeneity of multiple myeloma: pathogenesis, prognosis, and therapeutic implications. J Clin Oncol. 2011; 29:1893-7. 
29. Gurvich N, Perna F, Farina A, Voza F, Menendez S, Hurwitz J, Nimer SD. L3MBTL1 polycomb protein, a candidate tumor suppressor in del(20q12) myeloid disorders, is essential for genome stability. Proc Natl Acad Sci U S A. 2010; 107:22552-7.

30. Heyning FH, Jansen PM, Hogendoorn PC, Szuhai K. Arraybased comparative genomic hybridisation analysis reveals recurrent chromosomal alterations in primary diffuse large B cell lymphoma of bone. J Clin Pathol. 2010; 63:1095100.

31. Hacıhamdioğlu B, Hacıhamdioğlu D, Delil K. 22q11 deletion syndrome: current perspective. Appl Clin Genet. 2015; 8:123-32.

32. Vona B, Nanda I, Neuner C, Schröder J, Kalscheuer VM, Shehata-Dieler W, Haaf T. Terminal chromosome 4q deletion syndrome in an infant with hearing impairment and moderate syndromic features: review of literature. BMC Med Genet. 2014; 15:72.

33. Chen CP, Chang TY, Guo WY, Wu PC, Wang LK, Chern SR, Wu PS, Su JW, Chen YT, Chen LF, Wang W. Chromosome $17 \mathrm{p} 13.3$ deletion syndrome: aCGH characterization, prenatal findings and diagnosis, and literature review. Gene. 2013; 532:152-9.

34. Leroy C, Landais E, Briault S, David A, Tassy O, Gruchy N, Delobel B, Grégoire MJ, Leheup B, Taine L, Lacombe D, Delrue MA, Toutain A, et al. The 2q37-deletion syndrome: an update of the clinical spectrum including overweight, brachydactyly and behavioural features in 14 new patients. Eur J Hum Genet. 2013; 21:602-12.

35. Fernandez TV, García-González IJ, Mason CE, HernándezZaragoza G, Ledezma-Rodríguez VC, Anguiano-Alvarez VM, E’Vega R, Gutiérrez-Angulo M, Maya ML, GarcíaBejarano HE, González-Cruz M, Barrios S, Atorga R, et al. Molecular characterization of a patient with $3 p$ deletion syndrome and a review of the literature. Am J Med Genet A. $2008 ; 146 \mathrm{~A}: 2746-52$.

36. Morris CA, Mervis CB. Williams syndrome and related disorders. Annu Rev Genomics Hum Genet. 2000; 1:46184.

37. Gaballa MR, Besa EC. Myelodysplastic syndromes with 5q deletion: pathophysiology and role of lenalidomide. Ann Hematol. 2014; 93:723-33.

38. Siva K, Jaako P, Miharada K, Rörby E, Ehinger M, Karlsson G, Karlsson S. SPARC is dispensable for murine hematopoiesis, despite its suspected pathophysiological role in 5q-myelodysplastic syndrome. Leukemia. 2012; 26:2416-9.

39. Pellagatti A, Boultwood J. Recent Advances in the 5q- Syndrome. Mediterr J Hematol Infect Dis. 2015; 7:e2015037.

40. Ji J, Loo E, Pullarkat S, Yang L, Tirado CA. Acute myeloid leukemia with $\mathrm{t}(7 ; 21)(\mathrm{p} 22 ; \mathrm{q} 22)$ and $5 \mathrm{q}$ deletion: a case report and literature review. Exp Hematol Oncol. 2014; 3:8.

41. Komrokji RS, Padron E, Ebert BL, List AF. Deletion $5 \mathrm{q}$
MDS: molecular and therapeutic implications. Best Pract Res Clin Haematol. 2013; 26:365-75.

42. Boultwood J, Pellagatti A, Wainscoat JS. 5q- syndrome. Curr Pharm Des. 2012; 18:3180-3.

43. Salmena L, Poliseno L, Tay Y, Kats L, Pandolfi PP. A ceRNA hypothesis: the Rosetta Stone of a hidden RNA language? Cell. 2011; 146:353-8.

44. Sanchez-Mejias A, Tay Y. Competing endogenous RNA networks: tying the essential knots for cancer biology and therapeutics. J Hematol Oncol. 2015; 8:30.

45. Ergun S, Oztuzcu S. Oncocers: ceRNA-mediated cross-talk by sponging miRNAs in oncogenic pathways. Tumour Biol. 2015; 36:3129-36.

46. Cheng DL, Xiang YY, Ji LJ, Lu XJ. Competing endogenous RNA interplay in cancer: mechanism, methodology, and perspectives. Tumour Biol. 2015; 36:479-88.

47. Tay Y, Rinn J, Pandolfi PP. The multilayered complexity of ceRNA crosstalk and competition. Nature. 2014; 505:34452.

48. Bak RO, Mikkelsen JG. miRNA sponges: soaking up miRNAs for regulation of gene expression. Wiley Interdiscip Rev RNA. 2014; 5:317-33.

49. Poliseno L, Pandolfi PP. PTEN ceRNA networks in human cancer. Methods. 2015; 77-78C:41-50.

50. de Giorgio A, Krell J, Harding V, Stebbing J, Castellano L. Emerging roles of competing endogenous RNAs in cancer: insights from the regulation of PTEN. Mol Cell Biol. 2013; 33:3976-82.

51. Arancio W, Giordano C, Pizzolanti G. A ceRNA analysis on LMNA gene focusing on the Hutchinson-Gilford progeria syndrome. J Clin Bioinforma. 2013; 3:2.

52. Arancio W. A bioinformatics analysis of Lamin-A regulatory network: a perspective on epigenetic involvement in Hutchinson-Gilford progeria syndrome. Rejuvenation Res. 2012; 15:123-7.

53. Arancio W, Carina V, Pizzolanti G, Tomasello L, Pitrone M, Baiamonte C, Amato MC, Giordano C. Anaplastic Thyroid Carcinoma: A ceRNA Analysis Pointed to a Crosstalk between SOX2, TP53, and microRNA Biogenesis. Int J Endocrinol. 2015; 2015:439370.

54. Arancio W, Pizzolanti G, Genovese SI, Baiamonte C, Giordano C. Competing endogenous RNA and interactome bioinformatic analyses on human telomerase. Rejuvenation Res. 2014; 17:161-7.

55. Peng L, Yuan XQ, Li GC. The emerging landscape of circular RNA ciRS-7 in cancer (Review). Oncol Rep. 2015; 33:2669-74.

56. Chen LL, Yang L. Regulation of circRNA biogenesis. RNA Biol. 2015; 12:381-8.

57. Milligan MJ, Lipovich L. Pseudogene-derived lncRNAs: emerging regulators of gene expression. Front Genet. 2015; $5: 476$.

58. Johnsson P, Morris KV, Grandér D. Pseudogenes: a novel 
source of trans-acting antisense RNAs. Methods Mol Biol. 2014; 1167:213-26.

59. Pink RC, Carter DR. Pseudogenes as regulators of biological function. Essays Biochem. 2013; 54:103-12.

60. Mitra CK, Korla K. Functional, structural, and sequence studies of microRNA. Methods Mol Biol. 2014; 1107:189206.

61. Inui M, Martello G, Piccolo S. MicroRNA control of signal transduction. Nat Rev Mol Cell Biol. 2010; 11:252-63.

62. Shen J, Hung MC. Signaling-mediated regulation of MicroRNA processing. Cancer Res. 2015; 75:783-91.

63. Ha M, Kim VN. Regulation of microRNA biogenesis. Nat Rev Mol Cell Biol. 2014; 15:509-24.

64. Yates LA, Norbury CJ, Gilbert RJ. The long and short of microRNA. Cell. 2013; 153:516-9.

65. Pellagatti A, Cazzola M, Giagounidis A, Perry J, Malcovati L, Della Porta MG, Jädersten M, Killick S, Verma A, Norbury CJ, Hellström-Lindberg E, Wainscoat JS, Boultwood J. Deregulated gene expression pathways in myelodysplastic syndrome hematopoietic stem cells. Leukemia 2010; 24:756-64.

66. Wu SY, Yang X, Gharpure KM, Hatakeyama H, Egli M, McGuire MH, Nagaraja AS, Miyake TM, Rupaimoole R, Pecot CV, Taylor M, Pradeep S, Sierant M, et al. 2'-OMephosphorodithioate-modified siRNAs show increased loading into the RISC complex and enhanced anti-tumour activity. Nat Commun. 2014; 5:3459.

67. Slager SL, Goldin LR, Strom SS, Lanasa MC, Spector LG, Rassenti L, Leis JF, Camp NJ, Kay NE, Vachon CM, Glenn M, Weinberg JB, Rabe KG, et al. Genetic susceptibility variants for chronic lymphocytic leukemia. Cancer Epidemiol Biomarkers Prev. 2010; 19:1098-102.

68. Di Bernardo MC, Crowther-Swanepoel D, Broderick P, Webb E, Sellick G, Wild R, Sullivan K, Vijayakrishnan J, Wang Y, Pittman AM, Sunter NJ, Hall AG, Dyer MJ, et al. A genome-wide association study identifies six susceptibility loci for chronic lymphocytic leukemia. Nat Genet. 2008; 40:1204-10.

69. Li XL, Arai Y, Harada H, Shima Y, Yoshida H, Rokudai S, Aikawa Y, Kimura A, Kitabayashi I. Mutations of the HIPK2 gene in acute myeloid leukemia and myelodysplastic syndrome impair AML1- and p53-mediated transcription. Oncogene. 2007; 26:7231-9.

70. Valinezhad Orang A, Safaralizadeh R, Kazemzadeh-Bavili M. Mechanisms of miRNA-Mediated Gene Regulation from Common Downregulation to mRNA-Specific Upregulation. Int J Genomics. 2014; 2014:970607.

71. Vasudevan S. Posttranscriptional upregulation by microRNAs. Wiley Interdiscip Rev RNA. 2012; 3:311-30.

72. Portnoy V, Huang V, Place RF, Li LC. Small RNA and transcriptional upregulation. Wiley Interdiscip Rev RNA. 2011; 2:748-60.

73. Boultwood J1, Fidler C, Strickson AJ, Watkins F, Gama S, Kearney L, Tosi S, Kasprzyk A, Cheng JF, Jaju RJ,
Wainscoat JS. Narrowing and genomic annotation of the commonly deleted region of the 5q- syndrome. Blood. 2002; 99:4638-41.

74. Dweep H, Sticht C, Pandey P, Gretz N. miRWalk database: prediction of possible miRNA binding sites by "walking" the genes of 3 genomes. J Biomed Inform. 2011; 44:839-47.

75. Enright AJ, John B, Gaul U, Tuschl T, Sander C, Marks DS. MicroRNA targets in Drosophila. Genome Biol. 2003;5:R1.

76. Miranda KC, Huynh T, Tay Y, Ang YS, Tam WL, Thomson AM, Lim B, Rigoutsos I. A pattern-based method for the identification of MicroRNA binding sites and their corresponding heteroduplexes. Cell. 2006; 126:1203-17.

77. Lewis BP, Burge CB, Bartel DP. Conserved seed pairing, often flanked by adenosines, indicates that thousands of human genes are microRNA targets. Cell. 2005; 120:15-20.

78. John B, Enright AJ, Aravin A, Tuschl T, Sander C, Marks DS. Human MicroRNA targets. PLoS Biol. 2004; 2:e363. 